\title{
OPTIMASI TITANIUM DIOKSIDA DAN ASAM GLIKOLAT DALAM KRIM TABIR SURYA KOMBINASI BENZOFENON-3 DAN OKTIL METOKSISINAMAT
}

\section{OPTIMIZATION OF TITANIUM DIOXIDE AND GLYCOLIC ACID IN COMBINATION OF BENZOPHENONE-3 AND OCTYL METHOXYCINNAMATE SUNSCREEN CREAM}

\author{
Viddy Agustian Rosyidi, Wirawan Deni, Lidya Ameliana \\ Bagian Farmasetika, Fakultas Farmasi, Universitas Jember \\ Jl. Kalimantan 37, Jember 68121 \\ Email: viddy.farmasi@unej.ac.id (Viddy Agustian Rosyidi)
}

\begin{abstract}
ABSTRAK
Sinar ultraviolet (UV) memiliki dampak buruk, yaitu sinar UV-A mampu menyebabkan pigmentasi dan sinar UV-B mampu menginduksi eritema, melanogenesis, kerusakan DNA, dan karsinoma sel skuamosa. Dampak buruk sinar UV terhadap kulit dapat diatasi dengan penggunaan tabir surya. Pada penelitian ini dilakukan penentuan formula optimum dari kombinasi titanium dioksida dan asam glikolat pada krim tabir surya terhadap beberapa respon, yaitu $\mathrm{pH}$, viskositas, SPF, \% transmisi eritema, dan \% transmisi pigmentasi dengan rancangan formula desain faktorial. Empat formula krim tabir surya telah dibuat dengan perbedaan pada proporsi titanium dioksida dan asam glikolat. Formula optimum yang terpilih adalah kombinasi titanium dioksida dan asam glikolat dengan proporsi $1 \%: 0,5 \%$ yang memberikan prediksi respon paling baik.
\end{abstract}

Kata kunci: titanium dioksida, asam glikolat, tabir surya, krim, benzofenon-3, oktil metoksisinamat.

\begin{abstract}
Ultraviolet (UV) ray has bad effects on the skin, i.e.UV-A induced pigmentation and UV-B induced erythema, melanogenesis, DNA damage, and squamous cell carcinoma. These bad effects can be prevented by using sunscreen. The aims of this study were to optimize titanium dioxide and glycolic acid on sunscreen cream formulas according to their observed $\mathrm{pH}$, viscosity, SPF, \% of erythema transmission, and \% of pigmentation transmission using factorial design. Four sunscreen cream formulas with a different ratio of titanium dioxide and glycolic acid were observed. The optimum formula was a combination of titanium dioxide and glycolic acid at ratio of 1\%:0,5\%; whose the best predicted responses.
\end{abstract}

Key words: titanium dioxide, glycolic acid, sunscreen, cream, benzophenone-3, octyl methoxycinnamate. 


\section{Pendahuluan}

Sinar ultraviolet (UV) memiliki dampak buruk, yaitu sinar UV-A mampu menyebabkan pigmentasi pada kulit tanpa menimbulkan kemerahan terlebih dahulu (Rosita dan Purwanti, 2010) dan sinar UV-B dapat menginduksi eritema, melanogenesis, kerusakan DNA, dan karsinoma sel skuamosa (Caswell, 2001). Dengan dampak negatif yang ditimbulkan oleh sinar matahari tersebut, maka diperlukan adanya suatu perlindungan tabir surya.

Sediaan tabir surya adalah sediaan kosmetika yang biasanya diaplikasikan pada permukaan kulit dengan menyerap atau menyebarkan sinar matahari, dan melindungi kesehatan kulit manusia dari pengaruh negatif sinar UV akibat sinar matahari (Zulkarnain dkk., 2013). Tabir surya dibagi menjadi dua, yaitu pemblok fisik dan penyerap kimia. Tabir surya pemblok fisik bekerja memantulkan sinar UV, sedangkan tabir surya penyerap kimia bekerja menyerap sinar UV (Fields, 2008). Contoh tabir surya pemblok fisik, seperti titanium dioksida $\left(\mathrm{TiO}_{2}\right)$, zink oksida $(\mathrm{ZnO})$, kaolin, talk, dan magnesium oksida (MgO). Tabir surya penyerap kimia terbagi menjadi 2 , yaitu antiUV-A dan antiUV-B. Contoh senyawa tabir surya antiUV-A yaitu benzofenon-3 dan avobenzon, sedangkan untuk senyawa tabir surya antiUV-B yaitu oktil metoksisinamat dan oktil salisilat.

Kombinasi pemblok fisik dengan penyerap kimia mampu meningkatkan nilai SPF serta memperluas perlindungan terhadap sinar matahari, serta meminimalkan degradasi dalam stabilitas sediaan tabir surya karena paparan sinar UV. Efektivitas tabir surya dapat dipengaruhi oleh derajat keasaman $(\mathrm{pH})$. Semakin besar $\mathrm{pH}$ sediaan, maka nilai SPF in vitro akan semakin menurun (Suhaidah, 2013). Senyawa asam yang dapat meningkatkan efektivitas sediaan tabir surya adalah golongan Alpha Hidroxy Acid (AHA). AHA digunakan sebagai agen pengasam dan antioksidan (Draelos dan Thaman, 2006). Alpha Hydroxy Acid (AHA) adalah asam alfa hidroksi karboksilat termasuk garam dan esternya, terdiri dari: asam glikolat, asam laktat, asam malat, asam tartrat, asam mandelat, dan asam sitrat (BPOM $\mathrm{RI}, 2006)$.

Penelitian ini mengoptimasi $\mathrm{TiO}_{2}$ dan asam glikolat pada krim tabir surya kombinasi benzofenon-3 dan oktil metoksisinamat dalam basis vanishing 
cream dengan menggunakan desain faktorial. Respon yang teramati adalah efektivitas tabir surya secara in vitro (SPF, \% transmisi eritema, dan \% transmisi pigmentasi), $\mathrm{pH}$, dan viskositas.

\section{Metode Penelitian}

Alat dan Bahan

Peralatan yang digunakan
dalam penelitian ini adalah
spektrofotometer UV-Vis (Genesys 10S), neraca analitik (Adventure Ohaus), hot plate, $\mathrm{pH}$ meter digital (ElmetronCP502), alat penguji viskositas (Viscotester VT 04), alat uji daya sebar ekstensometer, alat-alat gelas, mortir, stamper, dan program Design Expert Trial 10.0.1 sebagai pengolahan data.

Bahan yang digunakan dalam penelitian ini adalah benzofenon-3 (Thornhill, Amerika Serikat), oktil metoksisinamat (Chemspec Chemical Pvt. Ltd, India), titanium dioksida (Huntsman, Italia), asam glikolat (CABB GmbH Pvt. Ltd, India), akuades (PT. Aneka Kimia, Indonesia), asam stearat, setil alkohol, simetikon, sorbitol, trietanolamin, tween 80 , dan methylene blue dari Brataco Chemical.

Jalannya Penelitian

1. Pembuatan sediaan krim tabir surya
Masing-masing dari fase minyak (benzofenon-3, oktil metoksisinamat, asam stearat, setil alkohol, dan simetikon) dan fase air (trietanolamin, tween 80, sorbitol, dan akuades) dilarutkan dalam cawan dan dipanaskan di atas hotplate dengan suhu $70{ }^{\circ} \mathrm{C}$, dikarenakan merupakan titik lebur dari asam stearat atau yang tertinggi dari keseluruhan bahan. Kemudian, fase minyak dan fase air dicampur bersamaan pada mortir panas dan diaduk secara konstan hingga terbentuk masa krim, lalu ditambahkan $\mathrm{TiO}_{2}$ dan asam glikolat, diaduk hingga homogen. Rancangan formula dapat dilihat pada Tabel 1.

2. Evaluasi sediaan krim tabir surya

Evaluasi sediaan krim tabir surya meliputi pengujian sifat fisikokimia dan efektivitas in vitro. Pengujian sifat fisikokimia terdiri dari pengujian organoleptis, $\mathrm{pH}$, viskositas, dan daya sebar. Pengujian efektivitas in vitro terdiri dari penentuan nilai SPF, persen transmisi eritema (\%TE), dan persen transmisi pigmentasi (\%TP).

Pengujian organoleptis sediaan krim tabir surya dilakukan dengan pengamatan visual yaitu warna, 
bentuk, tekstur, dan bau. Pengujian tipe krim dilakukan dengan memberikan reagen methylene blue (Alakh dkk., 2011), lalu diamati di bawah mikroskop. Pengujian $\mathrm{pH}$ dilakukan dengan mengukur $\mathrm{pH}$ masing-masing formula sediaan krim tabir surya menggunakan alat $\mathrm{pH}$ meter digital.

Tabel 1. Susunan formula krim tabir surya

\begin{tabular}{|c|c|c|c|c|}
\hline Bahan & $F(1)(\%)$ & $F(a)(\%)$ & $F(b)(\%)$ & $F(a b)(\%)$ \\
\hline Benzofenon-3 & & & & \\
\hline Oktil metoksi-sinamat & & & & \\
\hline Titanium dioksida & 0,5 & 2 & 0,5 & 2 \\
\hline Asam glikolat & 0,5 & 0,5 & 1 & 1 \\
\hline Setil alkohol & & & & \\
\hline Asam stearat & & & & \\
\hline Trietanolamin & & & & \\
\hline Sorbitol & & & & \\
\hline Tween 80 & & & & \\
\hline Simetikon & & & & \\
\hline Akuades & 67,9 & 66,4 & 67,4 & 65,9 \\
\hline Total & 100 & 100 & 100 & 100 \\
\hline
\end{tabular}

Pengujian homogenitas dilakukan menggunakan gelas objek. Sejumlah tertentu krim dioleskan pada gelas objek dan kemudian diamati secara visual (Dhase dkk., 2014). Pengujian viskositas dilakukan menggunakan alat viscotester VT 04. Pengujian daya sebar dilakukan menggunakan alat ekstensometer. Hasil penyebaran yang didapat kemudian dicatat melalui 4 sisi. Diameter krim yang diharapkan yaitu 5-7 cm (Garg dkk., 2002).
Pengujian SPF secara in vitro dilakukan menggunakan sediaan krim tabir surya dengan konsentrasi 20 ppm. Larutan dalam kuvet tebal 1 $\mathrm{cm}$ diamati dengan spektrofotometer UV-Vis pada panjang gelombang 290-400 nm dengan rentang pengamatan sebesar $1 \mathrm{~nm}$.

Pengujian \% transmisi eritema dilakukan menggunakan sediaan krim tabir surya dengan konsentrasi 20 ppm dalam pelarut isopropanol. 
Larutan dalam kuvet tebal $1 \mathrm{~cm}$ diamati dengan spektrofotometer UV-Vis pada panjang gelombang 292,5-337,5 $\mathrm{nm}$ dengan rentang pengamatan sebesar $5 \mathrm{~nm}$ (Petro, 1981).

Pengujian $\%$ transmisi pigmentasi dilakukan menggunakan sediaan krim tabir surya dengan konsentrasi 20 ppm dalam pelarut isopropanol. Larutan dalam kuvet tebal $1 \mathrm{~cm}$ diamati dengan spektrofotometer UV-Vis pada panjang gelombang 332,5-372,5 nm dengan rentang pengamatan sebesar $5 \mathrm{~nm}$ (Petro, 1981).

Data hasil pengujian yang diperoleh, digunakan untuk masingmasing respon sehingga dapat melengkapi persamaan umum $\mathrm{Y}=\mathrm{b} 0$ + b1XA + b2XB + b12XAXB (Bolton dan Bon, 1997). Overlay plot dan nilai desirability digunakan untuk mengetahui formula optimum yang diusulkan

\section{Hasil dan Pembahasan \\ Pengujian Organoleptis}

Pengujian

organoleptis

menunjukkan bahwa keempat formula memiliki karakteristik organoleptis bertekstur lembut, beraroma tidak menyengat, dan warna putih. Krim tabir surya yang dihasilkan memiliki aroma khas bahan aktif yang digunakan, yaitu oktil metoksisinamat. Hasil pembuatan krim tabir surya dilihat pada Gambar 1 dan pengujian organoleptis krim tabir surya dapat dilihat pada Tabel 2.

Tabel 2. Karakteristik formula krim tabir surya $(n=3)$

\begin{tabular}{cccccccc}
\hline Formula & Tekstur & Aroma & Warna & Tipe krim & $\begin{array}{c}\text { Daya } \\
\text { Sebar (cm) }\end{array}$ & pH & $\begin{array}{c}\text { Viskositas } \\
\text { (dPa.s) }\end{array}$ \\
\hline F(1) & Lembut & Tidak & Putih & minyak dalam & $7,633 \pm$ & $6,887 \pm$ & $64,667 \pm$ \\
& & menyengat & & air (o/w) & 0,503 & 0,00577 & 0,577 \\
F(a) & \multirow{2}{*}{ Lembut } & Tidak & Putih & minyak dalam & $6,333 \pm$ & $5,743 \pm$ & $86,333 \pm$ \\
& & menyengat & & air (o/w) & 0,451 & 0,00577 & 1,528 \\
F(b) & \multirow{2}{*}{ Lembut } & Tidak & Putih & minyak dalam & $6,533 \pm$ & $6,493 \pm$ & $95,667 \pm$ \\
& & menyengat & & air (o/w) & 0,252 & 0,00577 & 1,155 \\
F(ab) & \multirow{2}{*}{ Lembut } & Tidak & Putih & minyak dalam & $6,667 \pm$ & $5,663 \pm$ & $69,667 \pm$ \\
& & menyengat & & air (o/w) & 0,529 & 0,00577 & 1,155 \\
\hline
\end{tabular}




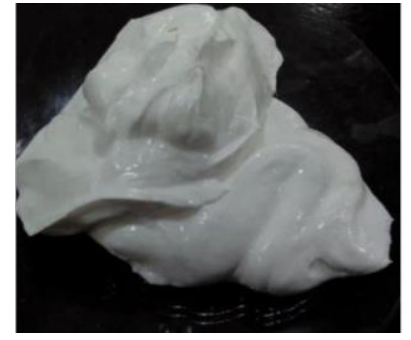

$F(0)$

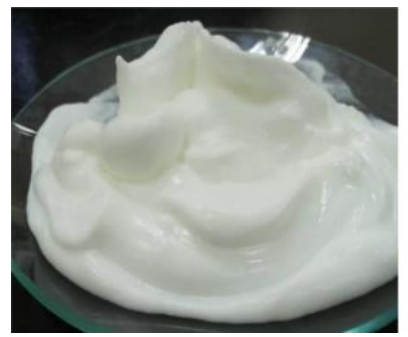

$F(b)$

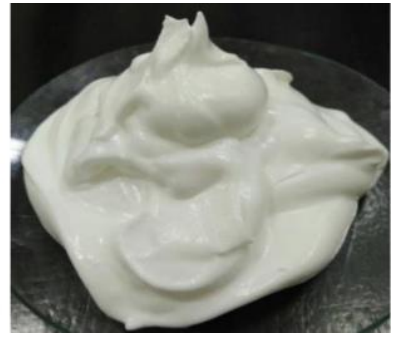

$F(a)$

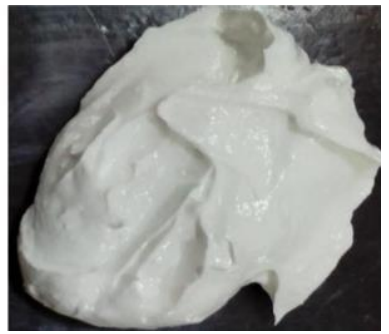

$\mathrm{F}(\mathrm{ab})$

Gambar 1. Hasil pembuatan krim tabir surya.

Pengujian Tipe Krim

$F(1), \quad F(a), \quad F(b)$, dan $F(a b)$ memiliki tipe krim sama, yaitu tipe minyak dalam air (o/w) sesuai dengan tipe emulsi yang diharapkan dari sediaan krim tabir surya ini. Hasil pengujian tipe krim dapat dilihat pada Tabel 2.

\section{Pengujian Homogenitas}

$$
\text { Pengujian homogenitas }
$$

menunjukkan keempat formula krim tabir surya memberikan susunan yang homogen dan tidak terdapat bintik- bintik bahan penyusun formula krim tabir surya. Sediaan krim yang homogen mengindikasikan bahwa ketercampuran secara merata dari bahan-bahan krim serta bahan aktif, sehingga tidak didapati gumpalan ataupun butiran kasar pada sediaan. Suatu sediaan krim harus homogen agar tidak menimbulkan iritasi dan terdistribusi merata ketika digunakan. Hasil pengujian homogenitas dapat dilihat pada Gambar 2. 


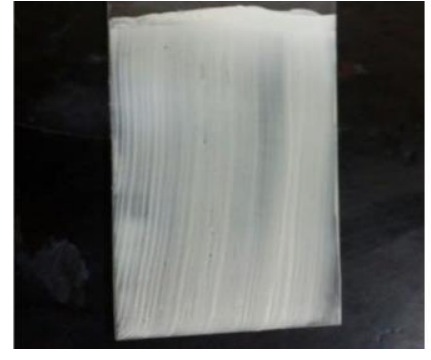

$F(0)$

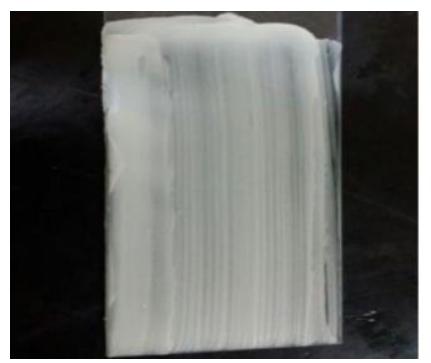

$F(b)$

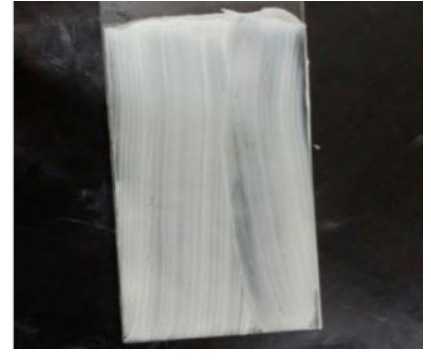

$F(a)$

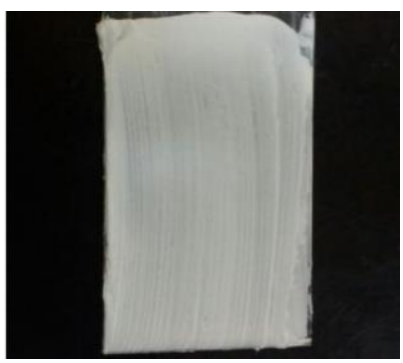

$F(a b)$

Gambar 2. Hasil pengujian homogenitas.

Pengujian Daya Sebar

Hasil pengujian daya sebar menunjukkan bahwa hanya $F(a), F(b)$, dan $F(a b)$ yang memiliki daya sebar yang memenuhi spesifikasi, yaitu antara 5-7 cm. Daya sebar suatu sediaan juga berhubungan dengan kemudahan pengaplikasian pada kulit. Krim yang mudah tersebar merata pada kulit, maka dapat menutupi kulit secara menyeluruh, sehingga lebih efektif dalam perlindungan kulit terhadap sinar
UV. Hasil pengujian daya sebar dapat dilihat pada Tabel 2.

Pengujian $\mathrm{pH}$

Krim yang memiliki $\mathrm{pH}$ terlalu basa dapat menyebabkan kulit kering dan bersisik, sedangkan jika terlalu asam dapat menimbulkan iritasi (Tranggano dan Latifah, 2007). Berdasarkan pengujian $\mathrm{pH}$, didapatkan bahwa urutan $\mathrm{pH}$ dari yang terbesar menuju terkecil adalah $F(1)>F(b)>F(a)>F(a b)$. Asam glikolat dan titanium dioksida memberikan efek 
menurunkan $\mathrm{pH}$ dengan nilai efek masing-masing sebesar 0,987 dan 0,237. Efek interaksi asam glikolat dan titanium dioksida dapat meningkatkan pH dengan nilai efek sebesar 0,157.

Asam glikolat memiliki nilai $\mathrm{pH}$ berkisar 0,08-2,75 (tanpa dapar), sehingga penambahan asam glikolat menurunkan pH sediaan (Sharad, 2013). Semakin banyak penggunaan asam glikolat pada krim tabir surya, dapat menurunkan $\mathrm{pH}$. Penurunan $\mathrm{pH}$ tersebut dikarenakan semakin besar konsentrasi ion $\mathrm{H}^{+}$dalam sistem. Hasil pengujian $\mathrm{pH}$ dapat dilihat pada Tabel 2.

Pengujian Viskositas

$$
\text { Berdasarkan pengujian }
$$

viskositas, didapatkan urutan viskositas dari tertinggi menuju terendah adalah $F(b)>F(a)>F(a b)>F(1)$. Titanium dioksida meningkatkan viskositas krim tabir surya dengan nilai efek sebesar 7,167; asam glikolat menurunkan viskositas dengan nilai efek sebesar 2,167; dan interaksi keduanya menyebabkan penurunan viskositas krim tabir surya dengan nilai efek sebesar 23,833.

Titanium dioksida mampu meningkatkan viskositas krim tabir surya, karena titanium dioksida praktis tidak larut dalam sediaan yang dibuat.
Asam glikolat mampu menurunkan viskositas, karena asam glikolat dapat larut dalam air, sehingga dengan mudah larut dalam sediaan yang dibuat. Interaksi keduanya juga menyebabkan penurunan viskositas krim tabir surya, karena diduga adanya interaksi antara titanium dioksida dan asam glikolat. Hasil uji viskositas dapat dilihat pada Tabel 2.

Penentuan Nilai SPF In Vitro Berdasarkan penentuan nilai SPF in vitro, dapat diketahui bahwa $F(1)$, $F(a)$, dan $F(b)$ masuk ke dalam kategori perlindungan maksimal karena memiliki nilai SPF antara 8-15, sedangkan F(ab) termasuk kategori perlindungan ekstra karena memiliki nilai SPF antara 6-7 (Harry, 1982). Titanium dioksida, asam glikolat, dan interaksi keduanya menurunkan SPF dengan nilai efek masing-masing sebesar 0,889;0,928; dan 1,372. Hasil penentuan nilai SPF in vitro dapat dilihat pada Tabel 3.

Penentuan Nilai \% Transmisi Eritema Berdasarkan penentuan nilai \% transmisi eritema, dapat diketahui bahwa keempat formula krim tabir surya yang dibuat termasuk dalam kategori sunblock, karena memiliki nilai $\%$ transmisi eritema < 1\% (Cumpelik, 1972). Titanium dioksida, asam glikolat, 
dan interaksi keduanya meningkatkan \% transmisi eritema dengan nilai efek masing-masing sebesar 0,000679;
0,00155; dan 0,000351. Hasil penentuan nilai \% transmisi eritema dapat dilihat pada Tabel 3

Tabel 3. Hasil penentuan aktivitas krim tabir surya in vitro $(n=3)$

\begin{tabular}{cccc}
\hline Formula & SPF In Vitro & \% Transmisi Eritema & \% Transmisi Pigmentasi \\
\hline$F(1)$ & $8,164 \pm 0,203$ & $0,00151 \pm 0,000422$ & $12,396 \pm 0,341$ \\
$F(a)$ & $8,608 \pm 0,223$ & $0,00270 \pm 0,000159$ & $11,568 \pm 0,209$ \\
$F(b)$ & $8,646 \pm 0,267$ & $0,00184 \pm 0,000927$ & $12,586 \pm 0,655$ \\
$F(a b)$ & $6,347 \pm 0,112$ & $0,00373 \pm 0,0000577$ & $14,411 \pm 0,524$ \\
\hline
\end{tabular}

Penentuan Nilai \% Transmisi Pigmentasi

Berdasarkan penentuan nilai \% transmisi pigmentasi, dapat diketahui bahwa keempat formula krim tabir surya yang dibuat termasuk dalam kategori sunblock, karena memiliki nilai \% transmisi pigmentasi pada rentang 340\% (Cumpelik, 1972). Titanium dioksida, asam glikolat, dan interaksi keduanya meningkatkan \% transmisi pigmentasi dengan nilai efek masingmasing sebesar 0,$499 ; 1,517$; dan 1,327 . Hasil penentuan nilai \% transmisi pigmentasi dapat dilihat pada Tabel 3.

Penentuan Daerah Optimum

$\begin{array}{ccc}\text { Dalam menentukan formula } \\ \text { optimum } & \text { dilakukan } & \text { dengan }\end{array}$

menggabungkan contour plot yang dihasilkan dari masing-masing respon $\mathrm{pH}$, viskositas, SPF, \%TE, dan \%TP menjadi overlay plot. Berdasarkan hasil overlay plot pada Gambar 3, daerah berwarna kuning merupakan daerah penunjuk jumlah titanium dioksida dan asam glikolat yang dapat memberikan kriteria respon yang diinginkan.

Didapatkan 11 formula yang diprediksikan dapat menghasilkan sediaan krim tabir surya dengan kriteria yang diharapakan. Formula optimum dengan nilai desirability tertinggi adalah formula dengan konsentrasi titanium dioksida dan asam glikolat masingmasing sebesar $0,5 \%$ dan $1 \%$. 


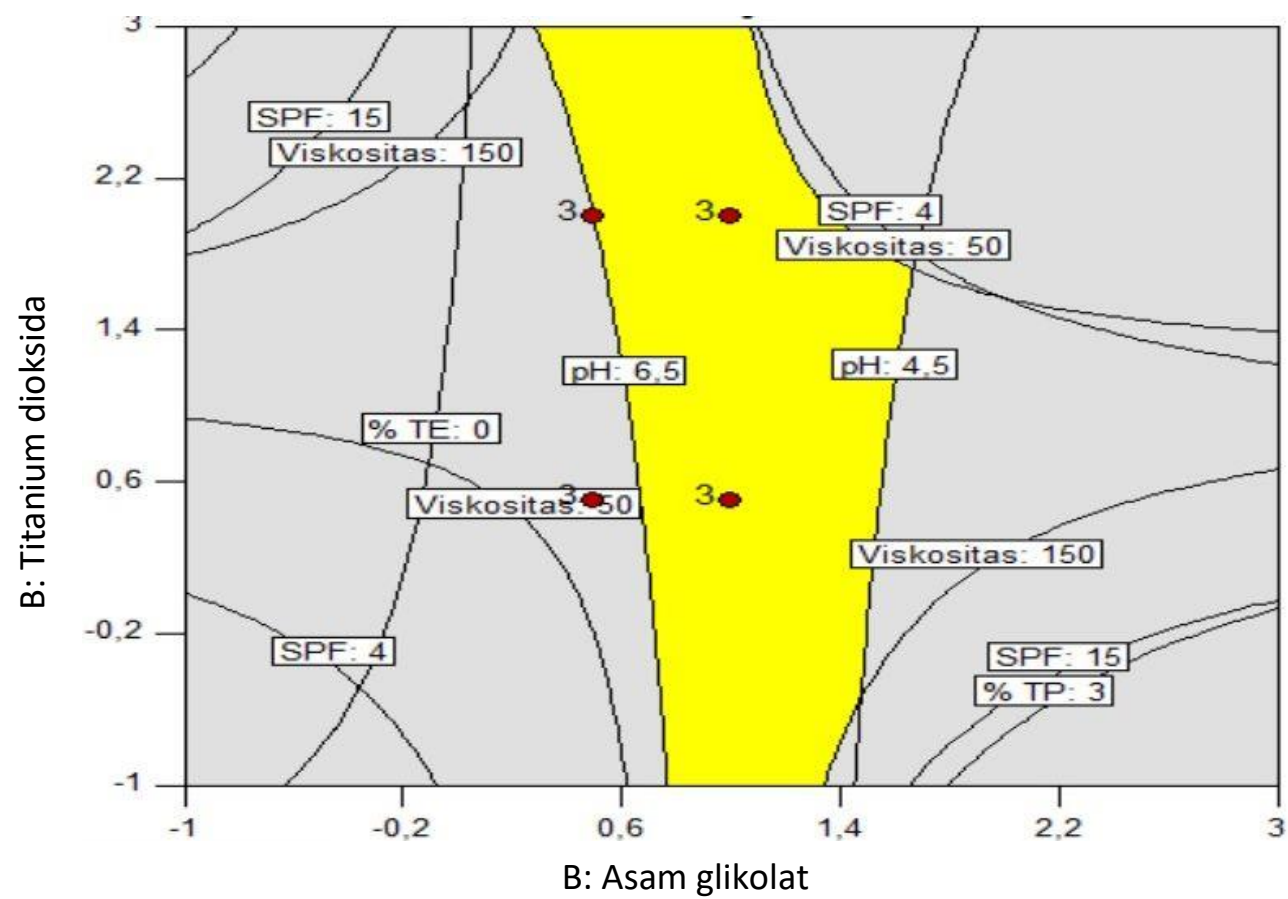

Gambar 3. Overlay plot daerah optimal.

\section{Kesimpulan}

Berdasarkan hasil penelitian, titanium dioksida, asam glikolat, dan interaksi keduanya memiliki pengaruh terhadap nilai $\mathrm{pH}$, viskositas, SPF, \%TE, dan \%TP. Komposisi optimum dari kombinasi titanium dioksida dan asam glikolat yang dapat digunakan, masingmasing sebesar $0,5 \%$ dan $1 \%$, pada sediaan krim tabir surya kombinasi benzofenon-3 dan oktil metoksisinamat. Formula optimum titanium dioksida dan asam glikolat menghasilkan respon $\mathrm{pH}$ sebesar 5,74; viskositas sebesar 86,33
dPa.S; SPF sebesar 8,607; \%TE sebesar 0,003; dan \%TP sebesar 11,568.

Perlu dilakukan uji stabilitas terhadap krim kombinasi benzofenon-3 dan oktil metoksisinamat dengan penambahan titanium dioksida dan asam glikolat. Uji aktivitas in vivo perlu dilakukan untuk mengetahui nilai SPF in vivo, sehingga dapat dibandingkan dengan hasil pengujian secara in vitro.

\section{Daftar Pustaka}

Alakh, S., Jha, S., dan Dubey, S.D. 2011. Formulation and evaluation of 
curcuminoid based herbal face cream. IGJPS, 1(1):77-84.

Bolton, S. dan Bon, C. 1997. Pharmaceutical Statistics: Practical and Clinical Aplication. Edisi III. New York: Marcel Dekker, Inc.

BPOM RI. 2006. Keputusan Kepala Badan Pengawas Obat dan Makanan Republik Indonesia Nomor HK. 00.06.42.0255 Tentang Petunjuk Teknis Pengawasan Alpha Hydroxy Acid dalam Kosmetik. Jakarta: BPOM RI.

Caswell, M. 2001. Sunscreen formulation and testing. Allured's Cosmetics and Toiletries, 116(9):49-60.

Cumpelik, B.M. 1972. Analitycal procedures and evaluation of sunscreen. J. Soc. Cosmet. Chem., 2:333-345.

Dhase, A.S., Khadbadi, S.S., dan Saboo, S.S. 2014. Formulation and evaluation of vanishing cream of crude drugs. American Journal of Ethnomedicine, 1(5):313-318.

Draelos, Z.D. dan Thaman, L.A. 2006. Cosmetic Formulation of Skin Care Products. New York: Taylor \& Francis Group.

Fields, S.W. 2008. Sunscreens: mechanisms of action, use, and excipients. IJPC, 6(1):4-5.

Garg, A., Anggarwal, D., Garg, S., Sigla, A.K. 2002. Spreading of semisolid formulation: an update.
Pharmaceutical Technology North America, 26(9):84-105.

Harry, R.G. 1982. Harry's Cosmeticology. Edisi Ketujuh. London: Leonard Hill Book.

Petro, A.J. 1981. Correlation of spectrophotometric data with sunscreen protection factor. International Journal of Cosmetic Science, 3:185-196.

Rosita, N. dan Purwanti, T. 2010. Sediaan tabir surya kombinasi oksibenson dan oktil metoksisinamat dengan penambahan asam glikolat. Majalah IImu Kefarmasian, 7(2):16-26.

Shaath, A.N. 1990. Sunscreen Development, Evaluation, and Regulatory Aspect: The Chemistry of Sunscreen. New York: Marcel Dekker, Inc.

Sharad, J. 2013. Glycolic acid peel therapy - a current review. Clinical, Cosmetic and Investigational Dermatology, 6:281-288

Suhaidah, I. 2013. Optimasi komposisi kombinasi $\mathrm{pH}$ dan lama paparan sinar UV terhadap efektifitas in vitro oktil metoksisinamat dalam krim tabir surya. Skripsi. Universitas Jember.

Tranggano, R.I.S. dan Latifah, F. 2007. Buku Pegangan Ilmu Pengetahuan Kosmetik. Jakarta: PT. Gramedia Pustaka Utama.

Zulkarnain, A.K., Susanti, M., Lathifa, A.N. 2013. The physical stability 
PHARMACY: Jurnal Farmasi Indonesia

p-ISSN 1693-3591

(Pharmaceutical Journal of Indonesia)

e-ISSN 2579-910X

Vol.15 No. 01 Juli 2018

of lotion $\mathrm{O} / \mathrm{W}$ and W/O from

Phaleria macrocarpa fruit extract

as sunscreen and primary irritation test on rabbit. Trad. Med. J., 18(3):141-150. 